\title{
Budgeting for covid-19: changing the narrative and narrating the change
}

\author{
Andy Cowper editor \\ Health Policy Insight, London, UK
}

The UK government's plan for dealing with covid-19 has now moved from the "contain" phase to the "delay" stage. ${ }^{1}$ This is just a recognition of reality. The World Health Organization has confirmed that the outbreak is now a pandemic, ${ }^{2}$ and the spread of disease is moving as expected. ${ }^{3}$ The move to the "delay" phase raises the question of what an effective UK reaction to pandemic covid-19 is going to look like, other than to buy us some preparation time.

ITV's political editor Robert Peston has a close working relationship with sources inside Boris Johnson's government, and his latest blog outlines the government's "herd immunity" strategy. ${ }^{4}$ It is worth quoting: "The strategy of the British government in minimising the impact ... is to allow the virus to pass through the entire population so that we acquire herd immunity, but at a much delayed speed so that those who suffer the most acute symptoms are able to receive the medical support they need, and such that the health service is not overwhelmed and crushed by the sheer number of cases it has to treat at any one time."

Peston reports that the government's plans are based on scientific advice that covid-19 cannot now be contained and that the draconian measures seen in China are likely only to delay its spread, which will resume once freedom of movement returns.

The budget on 11 March saw chancellor Rishi Sunak make promises of extra funding for the NHS to deal with the pandemic. ${ }^{5}$ This funding includes a £5bn (€5.7bn; \$6.3bn) contingency fund across the public sector to tackle covid- $19 .{ }^{6}$ The Treasury documents note that this is an initial figure, which could be increased if needed.

Given the past decade's political narrative on the need for austerity, readers might be forgiven for wondering where the chancellor will get this money. The Treasury's data, analysed by the independent Institute for Fiscal Studies, ${ }^{7}$ shows that it almost all comes from increasing government borrowing, financially facilitated by the Bank of England's emergency decision earlier that morning to cut the interest rate to $0.25 \%{ }^{8}$

The Institute for Fiscal Studies' analysis observes that "current spending per person for most public services will remain well below 2010-11 levels in 2024-25 . . . Outside of health though spending per person will still be $14 \%$ lower, and around $19 \%$ lower once you account for the spending that is simply replacing EU funding."

Only the most dreadful cynic would remark that the budget shows the government increasing the migrant health contribution to $£ 625$ a year (it was $£ 200$ when introduced in 2017). So of course I'm not going to do so. But it's a remarkable rate of inflation, isn't it? And bound to encourage international recruitment to the NHS, no doubt.

The budget addressed the important issue of the pensions taper tax by raising the annual income threshold to $£ 200000$ with a maximum annual employer contribution of $£ 40000 .^{9}$ This should help deal with the concerns of many senior doctors that they might be caught unawares by this tax and effectively have to pay to do the extra shifts the NHS greatly needs if it is to tackle long waiting times-let alone the effects of the covid-19 pandemic.

The Department for Health and Social Care capital budget is set to increase by $£ 1$ bn over previous plans: the extra money set for "estate refurbishments and building maintenance," according to Treasury documents. ${ }^{10}$ Meanwhile, the world of NHS management is seeing plans for a major increase in intensive care capacity. ${ }^{11}$ This is likely to raise concerns about how the increased capacity will be safely staffed.

There are also discussions about the prospect of stopping elective activity (following risk stratification) $)^{12}$ to increase capacity in the current system to respond to covid-19 demand. And the medical leaders of the NHS have issued a letter to medical staff seeking to reassure them that they will be "supported to work in new and unfamiliar ways." ${ }^{13}$

Another interesting moment in our recent politics came in a BBC News interview with former NHS chief executive David Nicholson, ${ }^{14}$ who is now chair of his local hospital in Worcester. Nicholson said that the government needs a "minister for covid" to coordinate policy across all of government. And he recommended former health secretary and new commons health select committee chair Jeremy Hunt for the job. 
The change in approach from "contain" to "delay" requires the public to trust those communicating this advice-and in the case of politicians, they don't, as I noted in The BMJ last week. ${ }^{15}$ Political populism has been a highly contagious global virus. There is a rich irony in how poorly that contagious virus prepared us for covid-19.

In Janan Ganesh's entertaining commentary for the Financial Times ${ }^{16}$ he cites $10 \%$ Less Democracy, a new book by economist Garett Jones arguing for more rule by the experts, or "epistocracy." It's the experts-the clinicians-who are on the front line, dealing with the covid-19 pandemic. Good luck, and take care.

Provenance and peer review: Commissioned; not externally peer reviewed. Competing interests: None declared.

1 BBC News (UK). Twitter. 12 Mar 2020. https://twitter.com/BBCNews/status/ 1238126516984258563

2 World Health Organization (WHO). Twitter. 11 Mar 2020. https://twitter.com/WHO/status/ 1237774421307228160

3 Public Health England. Total UK cases covid-19 cases update. https://www.arcgis.com/ apps/opsdashboard/index.html\#/f94c3c90da5b4e9f9a0b19484dd4bb14

4 Peston R. British government wants UK to acquire coronavirus "herd immunity," writes Robert Peston. ITV12 Mar 2020. https:/www.itv.com/news/2020-03-12/british-governmentwants-uk-to-acquire-coronavirus-herd-immunity-writes-robert-peston/
5 Treasury HM. Budget speech 2020. 11 Mar 2020. https://www.gov.uk/government/ speeches/budget-speech-2020

6 Norton T. £5bn contingency fund announced for coronavirus outbreak. HSJ 11 Mar 2020 https://www.hsj.co.uk/finance-and-efficiency/5bn-contingency-fund-announced-forcoronavirus-outbreak/7027106.article

7 Institute for Fiscal Studies. Spring Budget 2020: IFS analysis event. 12 Mar 2020. https: //www.ifs.org.uk/budget-2020

8 Bank of England. Bank of England measures to respond to the economic shock from Covid-19.11 Mar 2020. https://www.bankofengland.co.uk/news/2020/march/boe-measuresto-respond-to-the-economic-shock-from-covid-19

9 Budget 2020: Sunak moves to cure NHS pension taper crisis. Financial Timeshttps://www. ft.com/content/a961d588-3392-4182-8013-3abfcd3a64cf

10 Dunhill L. Chancellor lifts capital budget by £1bn next year. HSJ 11 Mar 2020. https:// www.hsj.co.uk/finance-and-efficiency/chancellor-lifts-capital-budget-by-1bn-next-year/ 7027108.article

11 Collins A. NHS seeks "seven-fold" surge in intensive care capacity. HSJ 11 Mar 2020. https://www.hsj.co.uk/workforce/nhs-seeks-massive-seven-fold-surge-in-intensive-carecapacity/7027104.article

12 Illman J. Exclusive: NHS prepares to cancel elective ops in readiness for covid-19 surge. HSJ 12 Mar 2020. https://www.hsj.co.uk/free-for-non-subscribers/exclusive-nhs-preparesto-cancel-elective-ops-in-readiness-for-covid-19-surge/7027110.article

13 Professor Chris Whitty. CMO England. Twitter. 12 Mar 2020. https://twitter.com/CMO_ England/status/1238044316762857472

14 PM. BBC Radio 4. 11 Mar 2020. https://t.co/DXgvWjwO47?amp=1

15 Cowper A. Covid-19: are we getting the communications right?BMJ 2020;368:m919. 10.1136/bmj.m919 32144115

16 Coronavirus and the comeback of the administrative state. Financial Timeshttps://www. ft.com/content/22ł51a26-6385-11ea-b3ł3-fe4680ea68b5

Published by the BMJ Publishing Group Limited. For permission to use (where not already granted under a licence) please go to http://group.bmj.com/group/rights-licensing/ permissions 